\title{
Heterogeneous rupture in the great Cascadia earthquake of 1700 inferred from coastal subsidence estimates
}

\author{
Pei-Ling Wang, ${ }^{1,2}$ Simon E. Engelhart, ${ }^{3,4}$ Kelin Wang, ${ }^{1,5}$ Andrea D. Hawkes, ${ }^{6,7}$ \\ Benjamin P. Horton, ${ }^{3,8}$ Alan R. Nelson, ${ }^{9}$ and Robert C. Witter ${ }^{10}$ \\ Received 9 January 2013; accepted 22 January 2013; published 15 May 2013.
}

[1] Past earthquake rupture models used to explain paleoseismic estimates of coastal subsidence during the great A.D. 1700 Cascadia earthquake have assumed a uniform slip distribution along the megathrust. Here we infer heterogeneous slip for the Cascadia margin in A.D. 1700 that is analogous to slip distributions during instrumentally recorded great subduction earthquakes worldwide. The assumption of uniform distribution in previous rupture models was due partly to the large uncertainties of then available paleoseismic data used to constrain the models. In this work, we use more precise estimates of subsidence in 1700 from detailed tidal microfossil studies. We develop a 3-D elastic dislocation model that allows the slip to vary both along strike and in the dip direction. Despite uncertainties in the updip and downdip slip extensions, the more precise subsidence estimates are best explained by a model with along-strike slip heterogeneity, with multiple patches of high-moment release separated by areas of low-moment release. For example, in A.D. 1700, there was very little slip near Alsea Bay, Oregon $\left(\sim 44.4^{\circ} \mathrm{N}\right)$, an area that coincides with a segment boundary previously suggested on the basis of gravity anomalies. A probable subducting seamount in this area may be responsible for impeding rupture during great earthquakes. Our results highlight the need for more precise, high-quality estimates of subsidence or uplift during prehistoric earthquakes from the coasts of southern British Columbia, northern Washington (north of $47^{\circ} \mathrm{N}$ ), southernmost Oregon, and northern California (south of $43^{\circ} \mathrm{N}$ ), where slip distributions of prehistoric earthquakes are poorly constrained.

Citation: Wang, P.-L., S. E. Engelhart, K. Wang, A. D. Hawkes, B. P. Horton, A. R. Nelson, and R. C. Witter (2013), Heterogeneous rupture in the great Cascadia earthquake of 1700 inferred from coastal subsidence estimates, J. Geophys. Res. Solid Earth, 118, 2460-2473, doi:10.1002/jgrb.50101.

\footnotetext{
${ }^{1}$ Earth and Ocean Sciences, University of Victoria, Victoria, British Columbia, Canada.

${ }^{2}$ Department of Geosciences, National Taiwan University, Taipei, Taiwan.

${ }^{3}$ Sea Level Research, Department of Earth and Environmental Science, University of Pennsylvania, Philadelphia, Pennsylvania, USA.

${ }^{4}$ Department of Geosciences, University of Rhode Island, Kingston, Rhode Island, USA.

${ }^{5}$ Pacific Geoscience Centre, Geological Survey of Canada, Sidney, British Columbia, Canada.

${ }^{6}$ Geology and Geophysics, Woods Hole Oceanographic Institution, Woods Hole, Massachusetts, USA.

${ }^{7}$ Geography and Geology, University of North Carolina Wilmington, Wilmington, North Carolina, USA.

${ }^{8}$ Institute of Marine and Coastal Sciences, Rutgers University, New Brunswick, New Jersey, USA.

${ }^{9}$ Geologic Hazards Science Center, United States Geological Survey, Golden, Colorado, USA

${ }^{10}$ Alaska Science Center, United States Geological Survey, Anchorage, Alaska, USA.

Corresponding author: K. Wang, Pacific Geoscience Centre, Geological Survey of Canada, 9860 West Saanich Rd., Sidney, BC V8L 4B2, Canada. (kwang@NRCan.gc.ca)

(C)2013. American Geophysical Union. All Rights Reserved. 2169-9313/13/10.1002/jgrb.50101
}

\section{Introduction}

[2] Although no great earthquakes have occurred along the Cascadia margin over its $\sim 200$ year written history, coastal stratigraphy shows unambiguous evidence for repeated, great megathrust earthquakes over the past $3000-7000$ years [Witter et al., 2003]. The most recent event occurred on 26 January A.D. 1700 , with a moment magnitude $\left(M_{w}\right)$ about 9 , as is inferred from stratigraphic evidence for coseismic subsidence and tsunami inundation along the western coast of North America (Figure 1) [Nelson et al., 1995; Atwater and Hemphill-Haley, 1997] and from historical records of tsunami waves that propagated across the Pacific Ocean to Japan [Satake et al., 2003; Atwater et al., 2005].

[3] To date, models for the 1700 earthquake have assumed a rather uniform rupture (of smoothly varying width) along the margin [e.g., Flück et al., 1997; Wang et al., 2003; Leonard et al., 2004, 2010]. Such a uniform pattern is quite different from the rupture patterns of any instrumentally recorded megathrust earthquakes at other subduction zones, for example, the recent $2004 M 9.2$ Sumatra [Chlieh et al., 2007], 2011 M 8.8 Maule (Chile) [Lorito et al., 2011], and 2011 M 9.0 Tohoku-Oki [e.g., Lee et al., 2011; Yokota et al., 2011; Wei et al., 2012] earthquakes. Along-strike variation in coseismic slip distribution is a primary feature of 


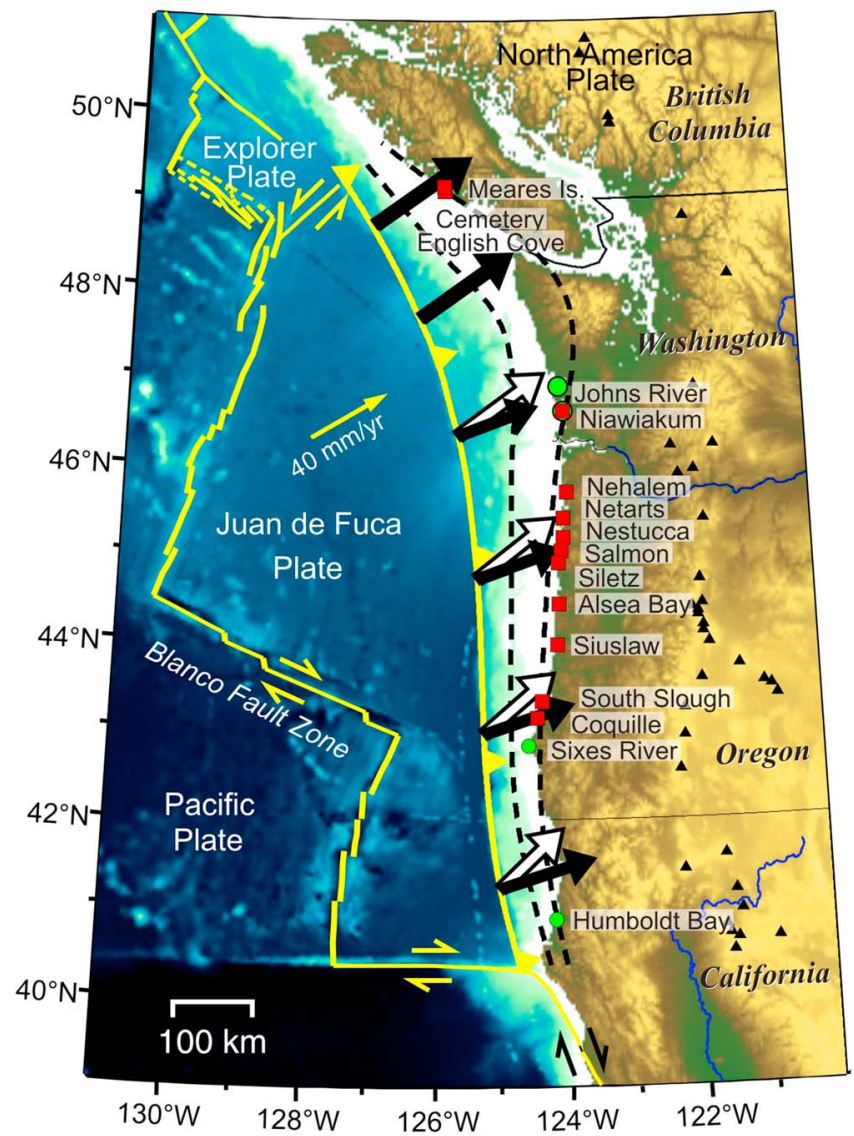

Figure 1. The Cascadia subduction zone and paleoseismic study sites cited in this paper. Black dashed lines represent previously used downdip limits of uniform coseismic slip zone and linear transition zone, corresponding roughly to the $350^{\circ} \mathrm{C}$ and $450^{\circ} \mathrm{C}$ isotherms, respectively, defined by Wang et al. [2003] and similar to Hyndman and Wang [1995] and Flück et al. [1997]. Black triangles denote volcanoes. White arrows: Juan de Fuca-North America (JDF-NA) plate convergence vectors. Black arrows: Juan de FucaCascadia fore arc convergence based on the model of Wells and Simpson [2001]. Euler poles for the relative plate motions are explained in Wang et al. [2003]. The shown JDF-NA convergence is similar to that predicted by the more recent model of DeMets et al. [2010]. Sites where paleoseismic estimates of coseismic subsidence in A.D. 1700 were obtained using the transfer function method are marked in red. Those that did not invoke transfer function are in green. At Niawiakum, Washington, both types of the estimates are available (Table 1). The Cemetery and English Cove sites on Vancouver Island are almost collocated.

earthquakes and gives rise to the concept of asperities, that is, patches of greater slip within areas of less slip. Because heterogeneous slip characterizes other subduction zone earthquakes, slip during great Cascadia earthquakes must also be heterogeneous. However, because of large errors, most geologic measurements of coseismic subsidence at subduction zones, even those for the $\sim M 9$ A.D. 1700 earthquake at Cascadia, cannot distinguish between subsidence patterns predicted by unifrom-slip or variable-slip models.
[4] In this paper, we test a model of variable slip at Cascadia against new, more precise estimates of coastal subsidence during the 1700 earthquake. The new or reevaluated data come from transfer function analyses of changes in assemblages of fossil foraminifera, a single-celled, marine organism with species sensitive to changes in relative sea level. More realistic models of Cascadia megathrust rupture will make future seismic and tsunami hazard assessments in this region more accurate. Our modeling also identifies the parts of Cascadia's coast where future microfossil-based estimates of coseismic subsidence will most improve future rupture models.

\section{Paleoseismic Estimates of Cascadia Coseismic Coastal Subsidence}

\subsection{Previous Estimates}

[5] Paleoseismic evidence for Cascadia megathrust earthquakes chiefly includes stratigraphic sequences of organicrich soils and sediment of coastal wetlands suddenly buried by tidal mud and sand [e.g., Darienzo et al., 1994; Atwater and Hemphill-Haley, 1997; Witter et al., 2003], with matching sudden changes in vascular plant fossils and microfossil assemblages [e.g., Atwater and Yamaguchi, 1991; Guilbault et al., 1995; Hughes et al., 2002], sometimes accompanied by tsunami-laid sand [e.g., Clague et al., 2000; Kelsey et al., 2002; Nelson et al., 2008], and/or liquefaction caused by strong shaking [Atwater, 1992; Takada and Atwater, 2004]. Radiocarbon dating of plant fossils in coastal stratigraphic sequences suggests recurrence intervals from less than a century to as much as a millennium, with an average of about 300-600 years [Atwater et al., 2004; Kelsey et al., 2005; Nelson et al., 2006]. Offshore turbidite deposits, inferred to have been induced by great-earthquake shaking, suggest the frequency is about 240 years in southern Cascadia [Goldfinger et al., 2012].

[6] Estimates of coseismic subsidence during past Cascadia megathrust earthquakes have been inferred from abrupt changes in sediment lithology or from apparently sudden changes in fossils in tidal stratigraphic sequences [e.g., Atwater and Yamaguchi, 1991; Hemphill-Haley, 1995; Peterson et al., 2000]. Such estimates were qualitative in nature because they inferred sudden changes from one intertidal environment to another (e.g., high marsh to tidal flat). Following measurement of the elevational ranges of modern intertidal environments, estimates of subsidence were derived by comparing the elevational ranges (typically $0.5-1.0 \mathrm{~m}$ ) for analogous paleoenvironments (inferred from lithology and/or fossils) from above and below stratigraphic contacts thought to mark subsidence during great earthquakes.

[7] Changes in the species assemblages of statistically significant numbers of intertidal microfossils (tens to hundreds in each sample), chiefly foraminifera and diatoms, perhaps gave more reliable estimates of sudden paleoenvironmental change than did individual plant fossils or lithology. However, as long as subsidence estimates were based on the elevational change from one paleoenvironment to another, errors on subsidence estimates remained $>0.5 \mathrm{~m}$ and commonly $>1 \mathrm{~m}$ [e.g., Nelson and Kashima, 1993; Nelson et al., 1996b; Witter et al., 2003; Hawkes et al., 2005; Leonard et al., 2010]. Because the elevational ranges of tidal environments vary from site to site, 
errors in these semi-quantitative subsidence estimates are difficult to assess [Nelson et al., 1996a].

[8] Beginning in the mid-1990s, Guilbault et al. [1995, 1996] and Shennan et al. [1996, 1998] pioneered the use of statistically based microfossil analysis in estimating coseismic subsidence across contacts in Cascadia tidal sequences. Shennan et al.'s [1996, 1998] use of ordination to quantitatively compare fossil assemblages of pollen and diatoms with modern assemblages of known elevation took full account of analysis errors. This multivariate technique orders microfossil assemblages so that similar assemblages are near each other and dissimilar assemblages are farther from each other. However, final subsidence estimates still relied on calculating a range of differences between the elevational ranges of preearthquake and postearthquake paleoenvironments. Guilbault et al.'s [1995, 1996] approach, now widely used to reconstruct climate-related sea level changes from microfossil assemblages beneath salt marshes [e.g., Horton et al., 1999; Horton and Edwards, 2006; Gehrels et al., 2008; Kemp et al., 2011], was fully quantitative in that subsidence estimates were directly calculated from fossil foraminiferal data using a transfer function calibrated with modern assemblage and elevation data from the same site. Their transfer function calculations yielded errors for subsidence estimates that were substantially smaller than the errors of previous methods $(<0.3 \mathrm{~m})$. We summarize transfer function analysis of microfossil data in section 2.2.

[9] In their comparisons of paleoseismic estimates of coseismic subsidence along the Cascadia subduction zone with a model of uniform slip, Leonard et al. [2004, 2010] strove to use as much information as possible from as many sites as possible. They compiled qualitative-to-quantitative subsidence values of variable quality collected by tens of investigators using different methods and assumptions developed over 15 years. Because the variable quality of the data resulted in large scatter and errors in subsidence estimates from the same or nearby sites, Leonard et al. [2010] weighted estimates based on inferred data quality and summarized them with moving-average values along the subduction zone. The weights were assigned based on factors such as the method used (qualitative, semiquantitative, or quantitative; lithology versus microfossil; etc.), the number of sites or samples analyzed, the number of estimates at the same site, and the precision of estimated errors. Estimates based on microfossil assemblages were given the highest weight, whereas estimates based on lithologic changes alone were assigned the lowest. Because of the large errors in the original data and the qualitative nature of the weight assignment, Leonard et al.'s [2010] average subsidence estimates cannot resolve along-strike variations in coseismic slip.

\subsection{Transfer Function Analysis}

[10] The transfer function method is briefly described here. For deeper discussion of the application in sea level and paleoseismology, see Horton and Edwards [2006], Shennan and Hamilton [2006], and Hawkes et al. [2011], respectively. Transfer functions are empirically derived equations used to calculate estimates of past environmental conditions from paleontological data [Imbrie and Kipp, 1971]. The equations express an environmental variable $(X)$ as a function of biological data $(Y)$ consisting of many species in many samples. The first step in transfer function analysis is development of a training data set of modern microfossil species assemblage distributions and corresponding environmental variables, in this case elevation relative to tide levels. To reconstruct relative sea level changes using fossil foraminiferal, diatom, or pollen assemblages in salt marsh sediment, modern assemblages are collected in surface samples along salt marsh transects from which $X$ and $Y$ are measured or identified, respectively [e.g., Horton and Edwards, 2006]. The analogous modern training set forms the basis for developing a transfer function. A range of software and statistical methods is available to generate the transfer function [Birks, 1995]. We use the C2 program [Juggins, 2011] and the weighted-average partial least squares (WA-PLS) method because it is rigorously supported by statistical theory and works well for species-rich, noisy data with environmental gradients [e.g., Birks, 1995]. Transfer functions transform microfossil data, typically collected from cores at a site where samples for the modern training set have also been collected, into a series of quantitative estimates of past tidal elevation at the site [e.g., Horton and Edwards, 2006]. We converted the elevations of modern samples into a standardized water level index [Horton et al., 1999] to account for variability in tidal range at each study site. Estimates of subsidence were then converted back to absolute values relative to the local tidal range of each fossil site.

\subsection{Paleoseismic Estimates Used in This Work Based on Transfer Functions}

[11] We reconstructed relative sea level changes caused by coseismic subsidence during the A.D. 1700 earthquake at 13 sites along the Oregon $(n=9)$, Washington $(n=1)$, and British Columbia $(n=3)$ coastline (Figure 1 and Table 1$)$. Thanks to improvements in data processing and transfer function analysis and the application of the method at many more sites [e.g., Hughes et al., 2002; Nelson et al., 2008; Hawkes et al., 2010, 2011; Engelhart et al., 2013], we now have a sufficient distribution of more precise estimates, most based on foraminiferal analyses, to investigate the along-strike slip variation during the 1700 earthquake. When possible, we assign a Gaussian probability distribution to each of the subsidence estimates based on the type of information, with one standard deviation expressed as the "error bar" (Table 1). In some cases, only the minimum value of the subsidence can be obtained. For example, at South Slough and Coquille River (Table 1), soil O horizons of forested wetlands had elevations too high to be inundated by the tide and hence lack foraminiferal assemblages representative of their pre-earthquake elevations.

[12] Five of the nine estimates from Oregon are those of Hawkes et al. [2011] who estimated subsidence at Nehalem $(0.49 \pm 0.31 \mathrm{~m})$, Nestucca $(0.47 \pm 0.28 \mathrm{~m})$, Salmon River $(0.60 \pm 0.29 \mathrm{~m})$, Siuslaw $(0.42 \pm 0.30 \mathrm{~m})$, and South Slough (minimum of $0.67 \mathrm{~m}$ ). Using an expanded regional foraminiferal transfer function [Engelhart et al., 2013], we developed a new WA-PLS transfer function that had a root-mean-square (RMS) error of prediction between observed and predicted values of $\pm 7 \%$ of tidal range. We applied this transfer function to fossil foraminiferal assemblages at Netarts Bay $(0.26 \pm 0.28 \mathrm{~m})$, Siletz River $(0.69 \pm 0.28 \mathrm{~m})$, and Coquille River (minimum of $0.81 \mathrm{~m})$ (Table 1). Hawkes et al. [2010] had obtained an estimate $(0.18 \pm 0.20 \mathrm{~m})$ for Alsea Bay, Oregon, using the data of Nelson et al. [2008]. Concerned by the differences between 
WANG ET AL.: GREAT CASCADIA EARTHQUAKE OF 1700

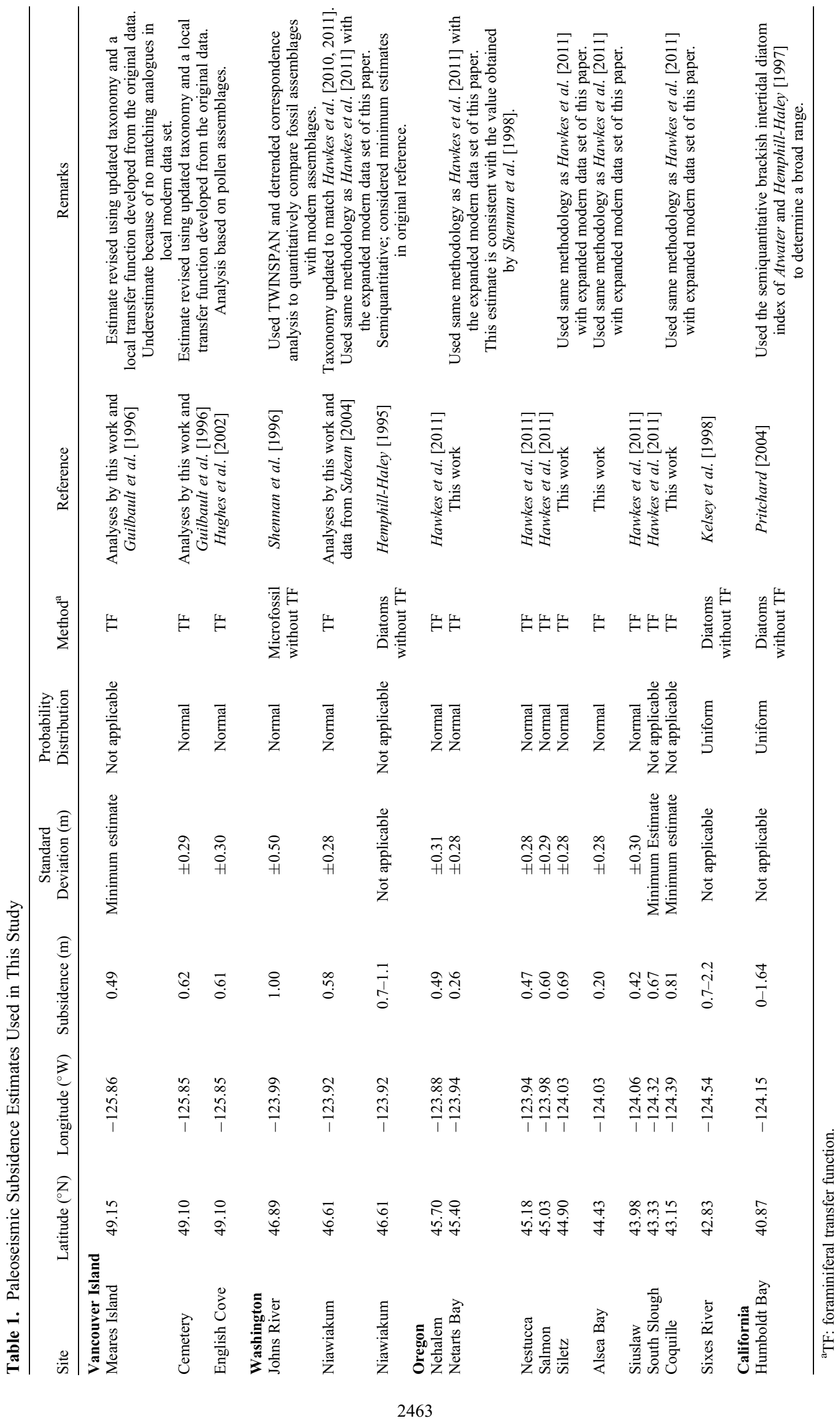


the foraminiferal taxonomy used by Nelson et al. [2008] and the taxonomy used by Hawkes et al. [2010], we resampled a new core from the Alsea Bay site. Our newly obtained subsidence estimate $(0.20 \pm 0.28 \mathrm{~m})$ is consistent with the previous value of Hawkes et al. [2010]. At the Niawiakum River, southern Washington, we reevaluated the fossil foraminiferal data of Sabean [2004] so that they are consistent with the taxonomy of Engelhart et al. [2013]. Because the species distribution of modern foraminifera in marshes of southern Washington is similar to the distribution in Oregon marshes, we used our expanded regional transfer function with Sabean's [2004] data to calculate a new subsidence estimate.

[13] All three British Columbia sites are in the Tofino area of western Vancouver Island. Using the same approach as for the Niawiakum River site, we updated the foraminiferal taxonomy of Guilbault et al. [1996] who studied the Meares Island and Cemetery sites near Tofino. Because of differences among modern foraminiferal distributions at the Tofino and Oregon sites, we developed a new local transfer function for the Tofino area based on the modern data of Guilbault et al. [1996] to calculate subsidence (Table 1). The RMS error of prediction (difference between the observed and predicted values) was $\pm 11 \%$ of the tidal range. Our foraminiferal estimate for the Cemetery site $(0.62 \pm 0.29 \mathrm{~m})$ is ecologically reasonable and is nearly identical to Hughes et al.'s [2002] value $(0.61 \pm 0.30 \mathrm{~m})$ based on transfer function analyses of pollen data from the neighboring English Cove site. The local transfer function may have underestimated subsidence at the Meares site $(0.49 \mathrm{~m})$ because of no matching modern assemblages. Therefore, we consider the subsidence estimated for this site to be a minimum value.

\subsection{Estimates From Microfossils Without Using Transfer Functions}

[14] In an effort to minimize spatial gaps in the subsidence data along the subduction zone, we reevaluated each of the subsidence estimates used by Leonard et al. [2004, 2010] by scrutinizing publications with the original data or, for some sites, referring to unpublished data. In most cases, large errors made the subsidence estimates of minimal use in our study of along-strike variations in subsidence and fault slip. In some cases, there was not sufficient information on how the estimates and their errors had been determined. However, we use subsidence estimates based on non-transfer function microfossil data from four sites because the error ranges for these data are better understood (Table 1 and Figure 1) and they help to minimize spatial data gaps.

[15] At Johns River, southwest Washington, Shennan et al. [1996] used ordination to compare quantitatively fossil assemblages of pollen, diatoms, and foraminifera with modern assemblages of known elevation. Modern pollen and diatom data were combined to define seven environmental zones, five of them corresponding to tidal elevational zones. Shennan et al. [1996] assigned fossil assemblages to one of the five elevational zones to calculate the maximum and minimum elevational changes across the contact marking subsidence during the 1700 earthquake. Using these changes, Shennan et al. [1996] estimated subsidence in 1700 at $1.0 \pm 0.5 \mathrm{~m}$.
[16] At the Niawiakum River, at Willapa Bay in southern Washington, Hemphill-Haley [1995] used semiquantitative analysis of diatom assemblages to obtain subsidence estimates consistent with those of Shennan et al. [1996] at the nearby Johns River. Hemphill-Haley [1995] interpreted her estimates of $\sim 0.7-0.8$ and $\sim 1.0-1.1 \mathrm{~m}$ (errors not specified) from two Niawiakum sites as minimum values and estimated a maximum subsidence up to $3 \mathrm{~m}$ on the basis of plant macrofossil and lithology data. Given the large errors in using plant macrofossil and lithology data to estimate subsidence as explained in section 2.1, we do not think this maximum estimate is reliable. This assessment is supported by Sabean's [2004] foraminiferal assemblages. The range of $0.7-1.1 \mathrm{~m}$ based on diatoms is more consistent with our new estimate of $0.58 \pm 0.28 \mathrm{~m}$ (Table 1), obtained by reanalyzing Sabean's [2004] unpublished foraminiferal assemblage data using the new transfer function. However, because there is some uncertainty in the taxonomy used by Sabean [2004] compared with Hawkes et al. [2011] that is not reflected in the formal error of 0.28 in our new estimate, we cannot simply replace Hemphill-Haley's [1995] estimates with our new value. Therefore, we show both estimates for this site in Table 1 and subsequent figures.

[17] At Sixes River, southern Oregon, Kelsey et al. [1998] concluded that changes in diatoms assemblages across the contact inferred to mark the 1700 earthquake are consistent with coseismic subsidence. Through reconstructing the response of the Sixes River to coseismic land level change, these authors further estimated that subsidence was at least $0.7 \mathrm{~m}$ and no more than $2.2 \mathrm{~m}$.

[18] At our southernmost site, Humboldt Bay (Figure 1), Pritchard [2004] used lithology and diatom assemblages to infer a sudden change from a low-marsh environment to a tidal flat across the abrupt contact marking the 1700 earthquake. Using the same approach as Hemphill-Haley [1995], we compared the elevational ranges of pre-earthquake and postearthquake environments inferred from diatom assemblages at this site and estimated the subsidence to be in the range $0-1.64 \mathrm{~m}$.

\subsection{Temporal Resolution of Coseismic Subsidence Estimates}

[19] Paleoseismic studies show evidence for sudden coastal subsidence that is most likely due to prehistoric earthquakes. However, these studies cannot define the "suddenness" to within minutes. Therefore, the inferred subsidence may not be truly coseismic and may be "contaminated" by postseismic deformation. Postseismic land level change is difficult to assess because no methods allow dating of sediment or fossils just above contacts of interest with errors of less than decades. If the Cascadia coast continued to subside for a few months or years following an earthquake, transfer function methods may overestimate the amount of coseismic subsidence. If the coast rapidly uplifted following coseismic subsidence, transfer function methods may underestimate subsidence. If postseismic motion reverses direction a short time after the earthquake, then transfer function methods may either overestimate or underestimate coseismic subsidence.

[20] Observations following recent subduction earthquakes do not show a consistent pattern of postseismic 
motion. After the 1964 Alaska earthquake, areas of coseismic subsidence were rising a few years after the earthquake [Cohen and Freymueller, 2001]. However, after the 2011 Tohoku earthquakes, some of the coastal areas that coseismically subsided continued to subside (http://www. gsi.go.jp/chibankansi/chikakukansi40005.html; in Japanese). Perhaps, some of these areas may reverse their sense of motion in the near future.

[21] From stratigraphic and microfossil evidence, we infer that our subsidence estimates record mainly coseismic rather than postseismic elevation change. The unusual sandy lithology of beds capping the 1700 contact at 10 or more of the 13 sites (Table 1), sedimentary structures indicative of pulses of suspension deposition of sand at some sites, and the smooth upward grading of sandy beds into intertidal mud are consistent with a rapid return to normal deposition of tidal sediment at these sites, probably within days of sand deposition by tsunamis [e.g., Guilbault et al., 1996; Hughes et al., 2002; Hamilton and Shennan, 2005; Nelson et al., 2008]. More importantly, diatom and foraminiferal assemblages in overlying tidal sediment match the in situ assemblages of intertidal flat environments suggesting that both microfossil groups recolonize tidal flat environments within weeks to a few months following coseismic subsidence. Postseismic land level change within days to a few months is likely to be much smaller than the coseismic change.

\section{Modeling Method}

\subsection{Basic Assumptions}

[22] To model coseismic deformation, we use the 3-D megathrust fault geometry of McCrory et al. [2004] with no simplifications. However, because the model is developed in an elastic half-space that has a flat surface, a trivial correction must be made to the fault depth [Flück et al., 1997; Wang et al., 2003] such that it approximately represents depth from the seafloor and ground surface, not from sea level.

[23] For the Cascadia megathrust, the only constraints for coseismic slip in past great earthquakes are paleoseismic and paleotsunami observations. Because of the lack of data coverage in the margin-normal direction, these data contain little information on the downdip extent of megathrust rupture. Therefore, an important assumption for all Cascadia coseismic models is that the rupture zone is limited within a certain temperature range in the dip direction [Hyndman and Wang, 1993, 1995]. Some early models assumed that coseismic fault slip was a scaled mirror image of interseismic fault locking inferred from contemporary geodetic observations [Flück et al., 1997]. This assumption has been shown to be inappropriate because viscoelastic mantle rheology strongly affects interseismic deformation [Wang et al., 2012]. Following previous works such as Hyndman and Wang [1995], Satake et al. [2003], Priest et al. [2010], and Leonard et al. [2010], we assume the rupture to be confined between the deformation front and the $450^{\circ} \mathrm{C}$ isotherm (Figure 1). For testing the model of variable slip along strike, the downdip limit is not critically important, but we nonetheless will test model sensitivity to this parameter.

[24] The direction of coseismic slip is assumed to be in the convergence direction between the Juan de Fuca plate and the Cascadia fore arc (JDF-fore arc) (Figure 1), as in Wang et al. [2003], Satake et al. [2003], and Priest et al. [2010]. Specifically, the JDF-fore arc motion is described using two Euler poles [Wang et al., 2003]. The Euler pole for the JDF-fore arc convergence, based on the fore arc-North America motion of Wells and Simpson [2001], applies from southern Washington southward. In British Columbia, the convergence is described simply by the Juan de Fuca-North America (JDF-NA) pole. In northern Washington, a linear transition between the two convergence fields is assumed. McCaffrey et al. [2007] described a more complex model of upper plate deformation. Considering uncertainties in the paleoseismic estimates (section 2.5) and the other simplifying assumptions discussed above, the difference between using the Wang et al. [2003] or McCaffrey et al. [2007] description is not significant.

\subsection{Slip Distribution in Dip and Strike Directions}

[25] The fault mesh consists of interconnected small triangular planar elements. Each element is assigned a slip vector as a point dislocation source. Deformation of the top surface of the model is the sum of all the point source dislocation solutions [Okada, 1985] over the entire fault mesh [Flück et al., 1997; Wang et al., 2003]. The Poisson's ratio is set to be 0.25 . For a uniform half-space, no other material properties are needed.

[26] Fault slip in our heterogeneous rupture models follows the bell shape function (Figure 2) in the downdip direction as proposed by Wang and He [2008] and applied by Priest et al. [2010]. After some typographical errors are corrected, the function is reproduced as follows:

$$
\delta\left(x^{\prime}\right)= \begin{cases}\frac{6}{q^{3}} x^{\prime 2}\left(\frac{q}{2}-\frac{x^{\prime}}{3}\right) & 0 \leq x^{\prime} \leq q \\ \frac{6}{(1-q)^{3}}\left(1-x^{\prime}\right)^{2}\left(\frac{1-q}{2}-\frac{1-x^{\prime}}{3}\right) & q \leq x^{\prime} \leq 1\end{cases}
$$

with $x^{\prime}=x / W$, where $x$ is the downdip distance from the upper edge of the rupture zone and $W$ is the local downdip width (Figure 3 ). The skewness parameter $q$ ranges from

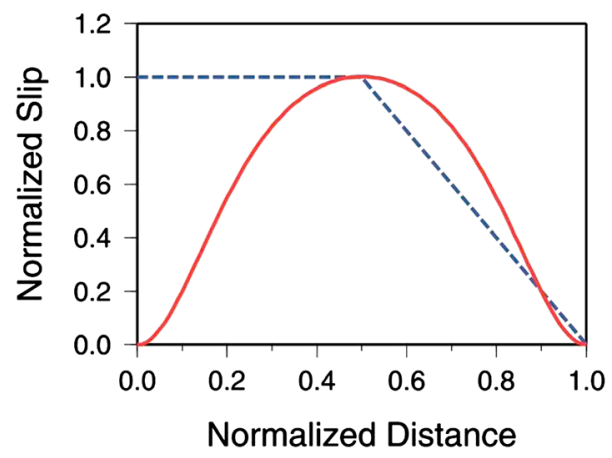

Figure 2. Two types of downdip distribution of coseismic slip. Linear slip function (blue dashed line) and bell shape function of Wang and He [2008] (red solid line). The bellshaped function has a broadness of 0.2 and a skewness of 0.5 (see equation (1)). 


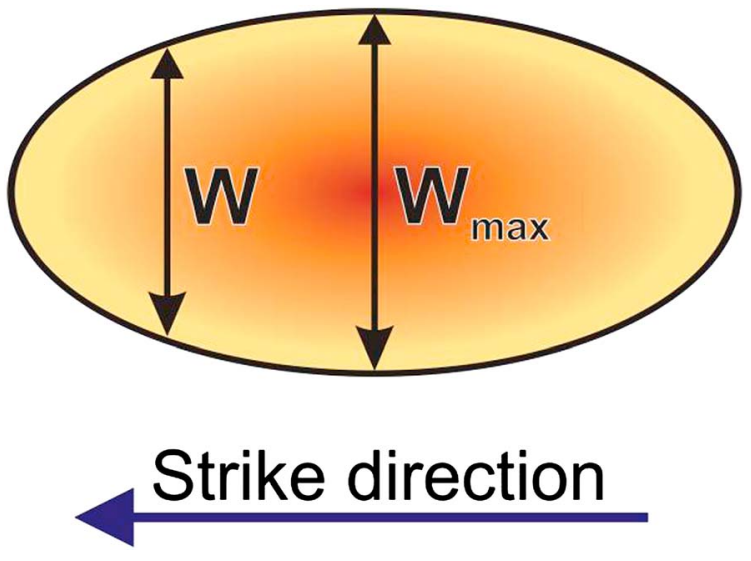

Figure 3. Definition of the local width $(W)$ and maximum width $\left(W_{\max }\right)$ of a slip patch. Warmer color means larger slip.

0 to 1 , and the broadness parameter $b$ ranges from 0 to 0.3 . The symmetric distribution shown in Figure 2, with $b=0.2$ and $q=0.5$, is used for all models of bell shape slip distribution in this work. Compared with the "linear distribution" (Figure 2), the bell shape function is more consistent with observed slip distribution in earthquakes and predictions of slip by rupture mechanics. However, details of the slip distribution in the dip direction, especially those of the updip end, are of no importance in modeling coastal subsidence. If we were to model the impact of tsunami waves on local coasts as in Priest et al. [2010], details of the shallow slip distribution would be very important.

[27] The most important issue we wish to investigate is along-strike slip variation. Here we represent high-slip areas in the simplest way, that is, as elliptical patches in which the slip peaks at the center and tapers toward the edge in all directions. The major axis of each ellipse is set to be approximately parallel to the local strike direction of the subduction fault (Figure 3). Where the margin geometry does not allow simple assignment of elliptical patches, such as the concave seaward corner off southern Vancouver Island and the Olympic Peninsula, or where the paleoseismic data are difficult to fit to simple patch shapes, we let the patches deviate from the elliptical shape. The slip magnitude is quadratically scaled with local width of the slip patch $\left(\left(W / W_{\max }\right)^{2}\right.$, see Figure 3$)$. Thus, there is less slip where the width of the patch is less than the widest part. The low-slip areas in our models are also referred to as "segment boundaries," but we do not imply that these are necessarily persistent features that behave in the same way in successive great earthquakes.

\subsection{Modeling Procedure}

[28] Models presented in this paper are summarized in Table 2 and will be described in section 4. We use a trial and error approach and adjust various model parameters such as the size, location, and peak slip for various patches and the number of patches by comparing model predictions with paleoseismic subsidence estimates. Because of the lack of strike-normal data coverage (section 3.1), there is no point pursuing a formal inversion.

[29] Despite our efforts to gather as many microfossil-based subsidence estimates as possible, there are still two large data gaps in northern and southern Cascadia (Figure 1). For areas of no data, we do not arbitrarily introduce segment boundaries except for testing purposes. Therefore, our preferred model necessarily features large patches in these areas. Future paleoseismic observations from these areas may change the rupture model.

[30] To explain tsunami waves that reached Japan in A.D. 1700, Satake et al. [2003] adopted the uniform-slip Cascadia rupture model of Wang et al. [2003] and tested different rupture widths and a scenario in which the rupture at the updip end was diverted to a splay fault. These trans-Pacific tsunami models are not sensitive to rupture details but provide constraints for the earthquake magnitude. They indicate a moment magnitude of 8.7-9.2 for the 1700 Cascadia event. We observe this magnitude range when developing our heterogeneous-slip models.

\section{Model Results}

\subsection{Uniform-Slip Models}

[31] We first construct two models of uniform slip to see how they compare with the more recent and precise subsidence estimates (Figure 4). Here as in Wang et al. [2003], Satake et al. [2003], and Leonard et al. [2004], "uniform" means that the equivalent time of slip deficit recovered by

Table 2. Slip Values and Earthquake Magnitudes of Different Models

\begin{tabular}{|c|c|c|c|c|c|}
\hline Model & Figure & Peak Slip ${ }^{\mathrm{a}}$ (years) & RMS (m) & $\operatorname{Moment}^{\mathrm{b}}(\mathrm{N} \mathrm{m})$ & $M_{w}$ \\
\hline \multirow{2}{*}{ Linear uniform } & $4 a, 4 c$ & 300 & 0.26 & $3.11+22$ & 8.9 \\
\hline & $4 \mathrm{c}$ & 500 & 0.73 & $5.18 \mathrm{E}+22$ & 9.1 \\
\hline Bell-shape uniform & $4 b, 4 c$ & 250 & 0.28 & $2.18 \mathrm{E}+22$ & 8.8 \\
\hline Modified uniform & 5 & 300 & 0.16 & $2.96 \mathrm{E}+22$ & 8.9 \\
\hline Preferred & $6 a, 6 c$ & $450,400,550,450$ & 0.18 & $2.33 \mathrm{E}+22$ & 8.8 \\
\hline Trench breaking & $6 b, 6 c$ & $450,400,550,450$ & 0.17 & $3.02 \mathrm{E}+22$ & 8.9 \\
\hline Wide & $8 \mathrm{a}, 8 \mathrm{~b}$ & $450,400,550,450$ & 0.40 & $2.70 \mathrm{E}+22$ & 8.9 \\
\hline Wide-200 & $8 \mathrm{a}, 8 \mathrm{~b}$ & $250,200,350,250$ & 0.28 & $1.49 \mathrm{E}+22$ & 8.7 \\
\hline Narrow & $8 a, 8 c$ & $450,400,550,450$ & 0.35 & $1.96 \mathrm{E}+22$ & 8.8 \\
\hline Narrow +200 & $8 \mathrm{a}, 8 \mathrm{c}$ & $650,600,750,650$ & 0.21 & $2.77 \mathrm{E}+22$ & 8.9 \\
\hline \multirow[t]{2}{*}{ Two-patch } & 10 & 450,300 & 0.28 & $2.05 \mathrm{E}+22$ & 8.8 \\
\hline & 10 & 450,500 & 0.41 & $2.33 \mathrm{E}+22$ & 8.8 \\
\hline Eight-patch & 10 & $450,450,500$ & 0.0 & & \\
\hline
\end{tabular}

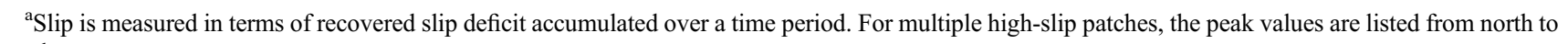
south.

${ }^{\mathrm{b}}$ The moment is calculated using a rigidity of $40 \mathrm{GPa}$. 


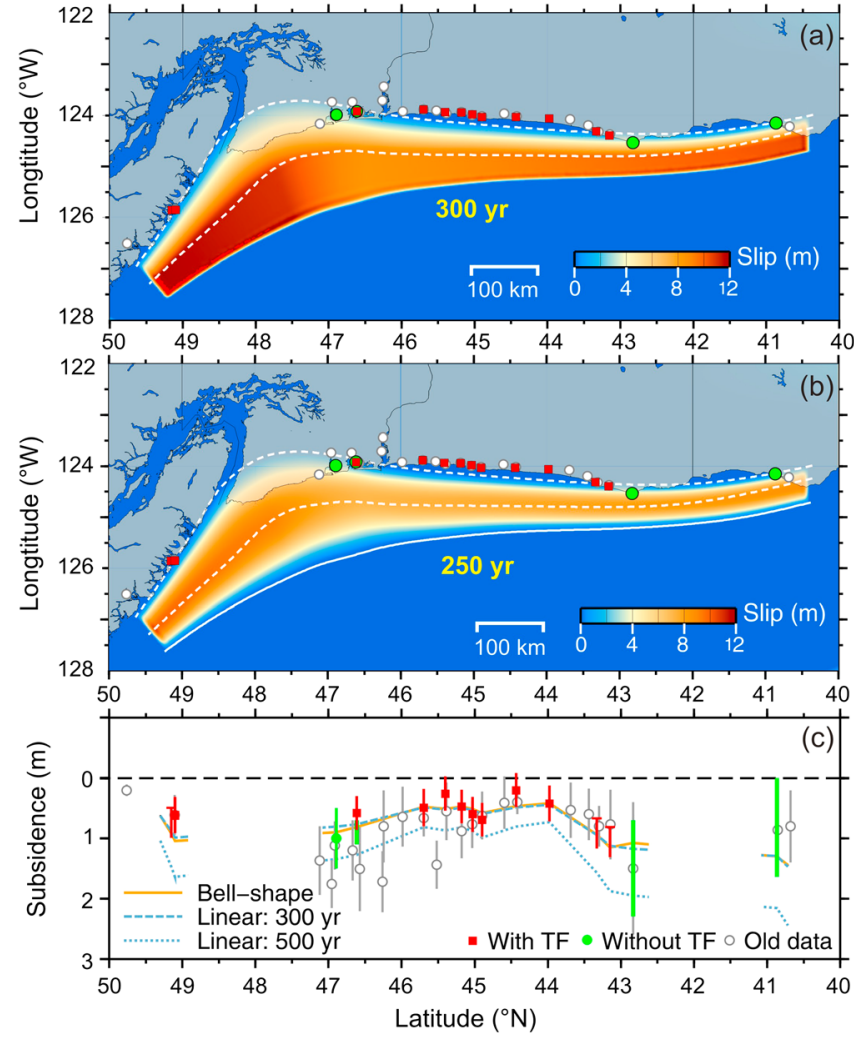

Figure 4. Models of uniform slip along strike (in terms of equivalent time of slip deficit accumulation). (a) Linear downdip slip distribution (see Figure 2), with slip equivalent to 300 years of slip deficit accumulation at current rate of JDF-fore arc convergence. The white dashed lines delineate the downdip limits of full-slip and transition zones (same as the black dashed lines in Figure 1). Sites of paleoseismic observations are color coded as in Figure 4c. (b) Bell shape slip distribution (see Figure 2), with 250 year slip. Other symbols are the same as in Figure 4a. (c) Model-predicted subsidence in comparison with paleoseismic estimates. TF: subsidence estimates derived from a microfossil transfer function. Uncertainties in the newer paleoseismic estimates (red and green symbols) are described as follows: symmetric error bars represent one standard deviation of normal probability distribution, one-sided bars indicate minimum subsidence estimate, and a bar with no symbol indicates uniform distribution. Note that the TF symbol with symmetric error bars at $49.10^{\circ} \mathrm{N}$ represents two estimates using different types of microfossils but with almost identical values (Cemetery and English Cove in Table 1). Older estimates, based mostly on nonmicrofossil data, used by Leonard et al. [2004, 2010] are shown as gray circles.

the coseismic slip is constant in the strike direction. In the rest of the paper, the amount of coseismic slip is always measured in terms of this equivalent time of slip deficit accumulation. For example, a 500 year slip means $20 \mathrm{~m}$ if the local convergence rate is $40 \mathrm{~mm} / \mathrm{yr}$ but $15 \mathrm{~m}$ if the local convergence rate is $30 \mathrm{~mm} / \mathrm{yr}$. It does not represent the actual time since the previous earthquake.

[32] Figure 4 shows subsidence values at the paleoseismic observation sites calculated using models with the linear and bell shape (Figure 2) downdip slip distributions. A 300 year slip for the linear distribution or a 250 year slip for the bell shape distribution can roughly fit the general trend of the paleoseismic estimates of coastal subsidence. The peak slip in the bell shape model is located more landward than that in the linear model (Figure 2), and hence, it requires slightly less slip to fit the paleoseismic estimates.

[33] The model of linear distribution with a 500 year slip is similar to the model of Leonard et al. [2004, 2010]. However, in calculating slip deficit to be recovered by an earthquake, Leonard et al. [2004, 2010] did not use a uniform convergence vector as in Flück et al. [1997] or the JDFfore arc convergence as in Satake et al. [2003] and this work. Instead, they used JDF-NA convergence extrapolated from the work of Wilson [1993] that features a convergence pattern at southern Cascadia similar to that shown by the white arrows in Figure 1. As a result, the margin-normal component of the coseismic slip off southern Oregon and northern California was quite small and fortuitously fitted the old paleoseismic data (gray circles in Figure 4c). Had the JDF-fore arc convergence been used, the model would have substantially overpredicted coseismic subsidence in this area (dotted line in Figure 4c).

[34] Although the uniform-slip models can roughly explain the trend of paleoseismic estimates, they do a poor job of explaining the second-order variations. One way to improve the fit is to vary the downdip extension of the rupture zone. For example, we can modify the model of Figure $4 \mathrm{a}$ in this fashion to produce the model shown in Figure 5a. Although this model can fit the paleoseismic estimates rather well (Figure 5b), the assumption of uniform slip is unrealistic as discussed in section 1.

\subsection{Preferred Model}

[35] Consistent with instrumental observations of great subduction earthquakes and based on the assumptions outlined in section 3.1, we propose a model of multiple high-slip patches for the A.D. 1700 great Cascadia earthquake (Figure 6a). It is called the preferred model in Table 2

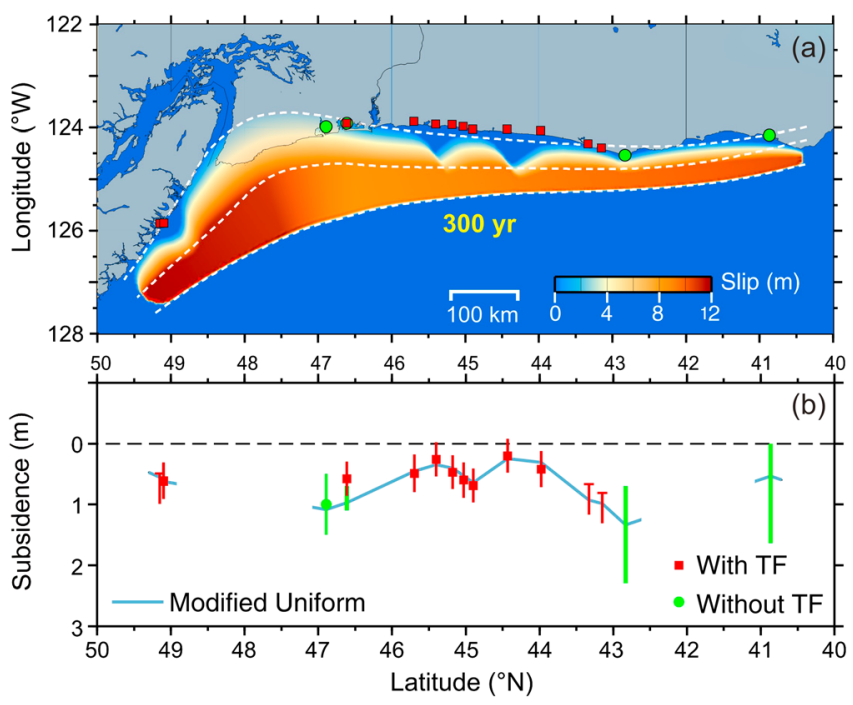

Figure 5. A uniform-slip model with downdip extension of the rupture zone varying along strike. (a) Slip distribution. (b) Model subsidence in comparison with paleoseismic estimates (Table 1). 
because we prefer this model over any uniform-slip models. Compared to other possible scenarios of heterogeneous rupture to be shown in section 4.4, the preferred model is simpler or fits the paleoseismic estimates better.

[36] In this model, we let the slip taper updip to become zero at the deformation front. The slip in all the patches peaks offshore and rapidly drops off at the coast except for the northernmost patch that extends further landward (Figure 6a). Because radiocarbon dating of subsidence contacts dates past earthquakes to only a century or two (rarely to several decades), the slip patches shown in Figure $6 \mathrm{a}$ could be interpreted as a sequence of smaller earthquakes over decades to a century. However, the scenario of all the patches rupturing in the same great earthquake is more consistent with the heights of the tsunami waves observed in Japan in 1700 [Satake et al., 2003].

[37] The preferred model fits the paleoseismic estimates in central Cascadia quite well (Figure 6c). Obviously, the slip in the northernmost and southernmost patches is poorly
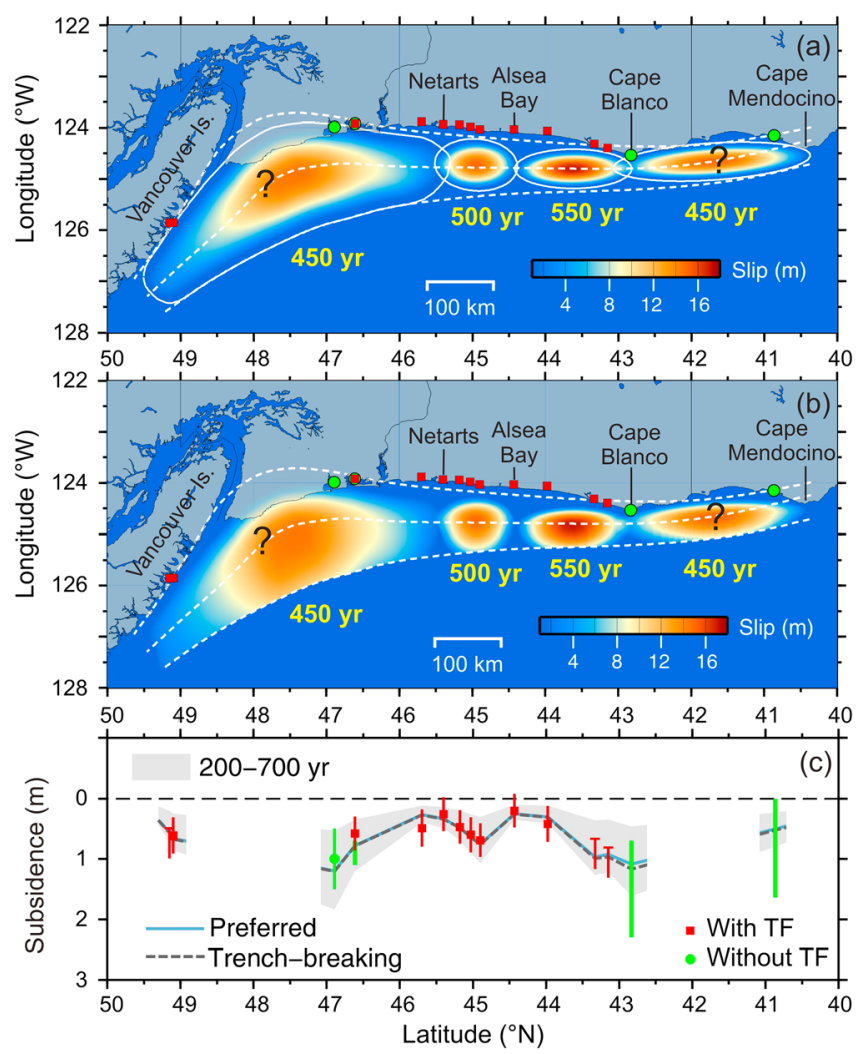

Figure 6. The preferred model and a trench-breaking rupture model for the 1700 Cascadia earthquake. (a) Slip distribution of the preferred model consisting of high-moment slip patches delineated by white lines. Peak slip (warmest color) labeled for each patch is measured in terms of equivalent time of slip deficit accumulation. The white dashed lines are the same as the black dashed lines in Figure 1. (b) Slip distribution of the trench-breaking rupture model. (c) Model-predicted coseismic subsidence in comparison with paleoseismic estimates (Table 1). The upper and lower bounds of the shaded area are obtained by assigning 200 year and 700 year slips, respectively, to all the four patches of the preferred model. constrained because of the paucity of quality paleoseismic subsidence estimates in these areas. The two existing microfossil-based estimates at Cape Blanco and Cape Mendocino did not use transfer functions, and their large uncertainties would allow a wide range of slip values for the southernmost patch. For a working model, we assume a value of 450 years, the average of the 200-700 year range (the shaded area in Figure 6c), for this patch.

[38] To accommodate a reviewer's request to "quantify" model fit, we list in Table 2 the RMS of model fit to the paleoseismic subsidence estimates. However, we do not attach much significance to these values. As explained in sections 3.1 and 3.3, no data can uniquely "resolve" the 1700 rupture. Given the sparse observational constraints, any model of the 1700 earthquake must be based on scientific reasoning and physically plausible assumptions such as those outlined in section 3.1. Consistency with paleoseismic data is a necessary but far from sufficient condition. For example, the modified uniform model (Figure 5) fits the paleoseismic estimates very well (very low RMS), but we do not prefer this model for reasons explained in section 4.1. All the other models in Table 2 are designed simply to illustrate the effects of changing poorly defined parameter values, not to show the preferred model to be "better resolved." With a great deal of tweaking, some of the nonuniform models in Table 2 can have an RMS as small as that of the preferred model.

[39] The RMS may provide some measure of how one specific parameter affects model fit if other parameters are fixed. For example, if we move the Alsea Bay, Oregon, segment boundary away from its visually determined best latitudinal location $\left(44.4^{\circ} \mathrm{N}\right)$, the RMS of the model will become larger (Figure 7).

[40] Obviously, the Alsea Bay boundary is needed by the preferred model because paleoseismic data from this area indicate little subsidence (Figure 6c). The boundary near Netarts Bay is introduced in order to explain the shortwavelength along-strike variations in coastal subsidence in this area. The third boundary, off Sixes River near Cape Blanco, is introduced mainly to limit the potentially large subsidence at this site. Although this boundary may not

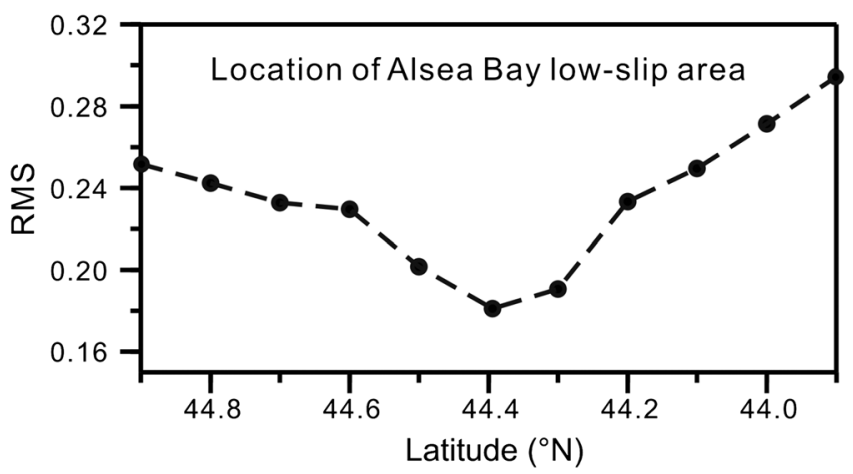

Figure 7. RMS fit to all paleoseismic estimates with slightly different locations of the Alsea Bay low-slip area (solid circles). All other model parameters are exactly the same as those of the preferred model of Figure 6a which appears as the minimum-RMS model here. 
be well constrained by the data, Witter et al. [2003] inferred that some past earthquake ruptures were limited by a segment boundary at Cape Blanco because paleoseismic records differ to the north and south of this latitude.

[41] The boundaries do find some support from their apparent correlation with other geological and geophysical observations or inferences. For example, near the low-slip areas offshore of Netarts and Alsea Bays, Han et al. [2012] and Tréhu et al. [2012] reported the presence of subducting seamounts. Wang and Bilek [2011] suggested that subducting seamounts should create an unfavorable condition for large seismic slip and act as barriers during great earthquakes. Several studies have proposed a segmentation boundary at Cape Blanco. Goldfinger et al. [2012] postulated that the Blanco fault zone (Figure 1) may give rise to a segment boundary here. Using large-scale ambient noise tomography, Porritt et al. [2011] proposed a strong shear velocity contrast in this area. Both the Alsea Bay and Cape Blanco boundaries roughly coincide with boundaries of offshore basins inferred from gravity lows by Wells et al. [2003].

\section{3. "Trench-Breaking" Rupture}

[42] During the $2011 M 9.0$ Tohoku earthquake in Japan, megathrust rupture extended to the trench, as inferred from repeat bathymetric and seismic surveys off the Sendai coast [Fujiwara et al., 2011; Kodaira et al., 2012]. Although the shallowest portion of the megathrust is generally believed to have a velocity-strengthening behavior that tends to retard slip, whether it can prevent such a trench-breaking rupture depends on the degree of its coseismic strengthening and the size of the earthquake [Hu and Wang, 2008], especially if dynamic weakening is involved [e.g., Noda and Lapusta, 2013]. It is not yet clear whether very large slip at the trench is a general feature of the Tohoku rupture or is limited to a relatively small area. Nor is it known whether this behavior is common in all subduction zones. It is possible that the 1700 Cascadia earthquake might also have ruptured the shallowest part of the fault. If the shallow rupture causes significant seafloor uplift near the base of the continental slope, it can be very effective in generating tsunami waves because of the large water depth.

[43] To account for the possibility of a trench-breaking rupture, we modify the preferred model to produce a model in which the slip does not become zero at the deformation front (Figure 6b). Although the Cascadia subduction zone does not have a bathymetric trench because of the large amount of sediment, we still call this model the trenchbreaking rupture model (Table 2). The downdip half of the slip patches is the same as in the preferred model, but the updip half is widened $50 \%$ seaward and truncated by the deformation front (Figure 6b). The model-predicted coastal subsidence is nearly identical to that of the preferred model (Figure 6c). The magnitude of this model earthquake is 9 . The magnitude can be further increased by assigning even larger slip near the trench, but the coseismic coastal subsidence will be little affected. Unless the trench-coast distance is very small, coastal subsidence estimates contain no information on the rupture behavior of the most updip portion of the megathrust rupture. The message of this test is simply that present Cascadia paleoseismic observations do not rule out trench-breaking rupture.

\subsection{Trade-off Between Rupture Width and Slip Magnitude}

[44] Because all the paleoseismic observations are located on the coast (Figure 1), for each latitude (study site), there is only one data point in the strike-normal direction. Thus, the updip and downdip termination of the seismogenic zone cannot be independently constrained by paleoseismic observations unless their strike-normal coverage can be substantially widened. Models in this section (Figure 8) are designed to illustrate how the ambiguity in the downdip rupture width affects the estimated slip magnitude. The along-strike slip distribution and the positions of the updip boundaries of the slip patches are identical to those of the preferred model. To produce wider or narrower ruptures, the lower boundaries of the patches are moved landward or seaward by $30 \%$, respectively (Figure 8a).

[45] With the same peak slip as in the preferred model, the Wide model generally results in larger coastal subsidence (Figure 8b). A 200 year decrease in slip better fits most of the paleoseismic estimates. On the other hand, with the same

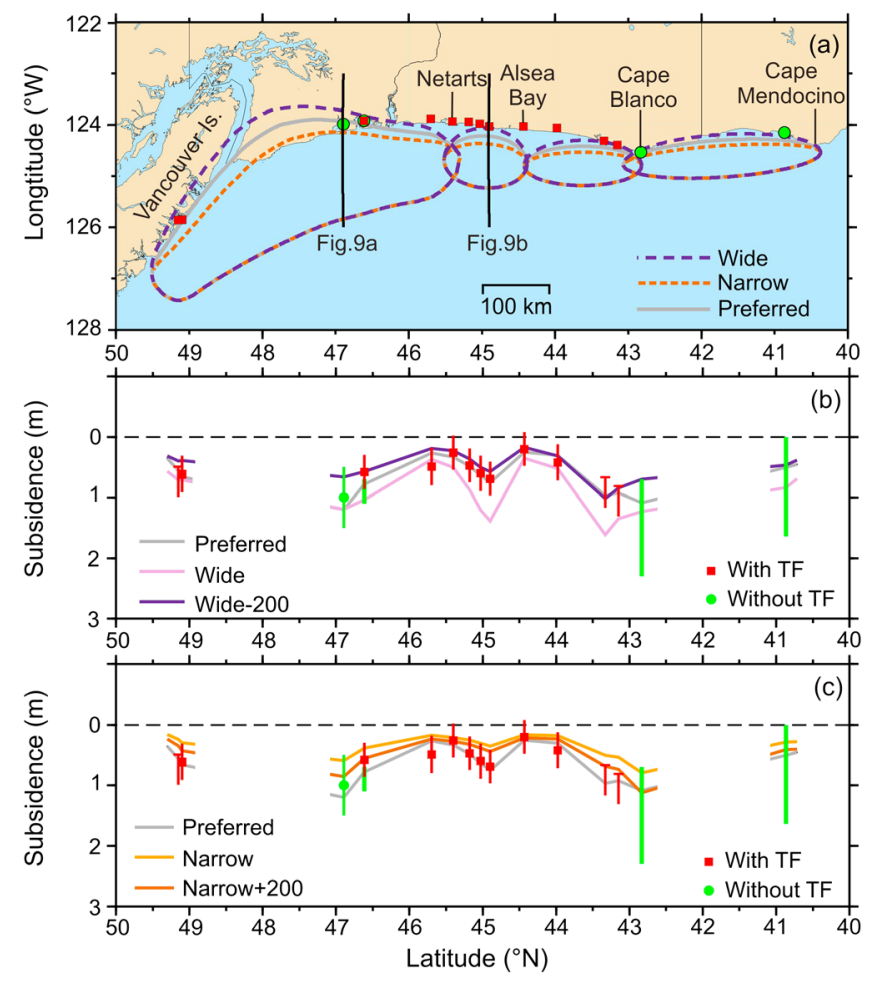

Figure 8. Tests for the effects of different downdip rupture widths. (a) Outlines of high-slip patches (slip distribution is similar to that shown in Figure 6a). For Wide and Narrow models, the downdip width is increased or decreased by $30 \%$ from the preferred model of Figure 6a. Deformation along the two margin-normal profiles will be shown in Figure 9. (b) Model subsidence for wider ruptures. In the wide model, peak slip is the same as that of the preferred model. In the Wide-200 model, the peak slip for each patch is that of the preferred model minus 200 years. (c) Model subsidence for narrower ruptures. In the Narrow model, the peak slip is the same as that of the preferred model. In the Narrow +200 model, the peak slip for each patch is that of the preferred model plus 200 years. 
peak slip as the preferred model, the Narrow model results in smaller subsidence (Figure 8c). A 200 year or greater increase in slip can better fit the paleoseismic data (Figure 8c). The resultant slip of 650-750 years or greater may be too large when compared to the average recurrence interval of great Cascadia earthquakes of about 500 years although not impossible considering the full recurrence range of 200-1000 years. Therefore, there are two main messages from these tests. First, downdip rupture width and slip magnitude cannot be independently inferred from coastal subsidence estimates. Second, ruptures much narrower than that of the preferred model with correspondingly larger slip appear to be less realistic than somewhat wider ruptures with smaller slip.

[46] The trade-off between rupture width and slip magnitude can be better explained using margin-normal profiles of deformation (Figure 9). If the coast is landward of the peak subsidence such as at site Siletz (Figure 9b) and most of our paleoseismic observation sites, a wider rupture causes greater subsidence for the same slip value. The model-predicted subsidence scales linearly with the assigned fault slip. In order to fit the paleoseismic estimate, a smaller or larger slip must be assigned to the Wide or Narrow models, respectively. However, if the coast is seaward of the peak subsidence such as for the Wide model at Johns River (Figure 9a), moving the lower boundary of the rupture patch landward will decrease, not increase, coastal subsidence. This is why the Wide model and the preferred model produce similar subsidence at this site.

\subsection{Other Scenarios of Along-Strike Variations}

[47] To illustrate the effect of low-slip areas on surface deformation and to explain how we introduce the three segment boundaries shown in Figure 6, we show two test models with different numbers of slip patches (Figure 10). For these tests, we let the slip taper to zero at the deformation front as in the preferred model shown in Figure $6 \mathrm{a}$, but the conclusions do not change if we use a trench-breaking model as in Figure $6 \mathrm{~b}$ instead.

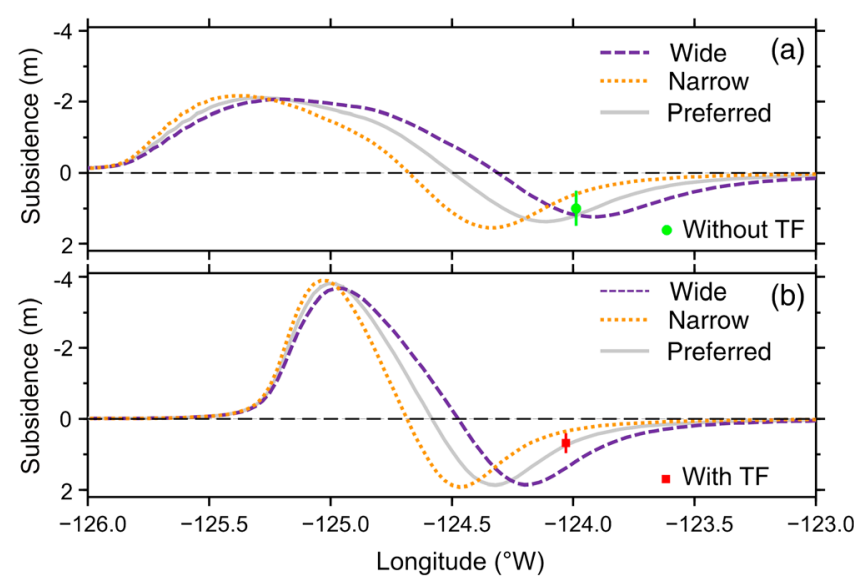

Figure 9. Model-predicted vertical motion for the preferred, Wide, and Narrow models along the margin-normal profiles shown in Figure $8 \mathrm{a}$ and the nearest paleoseismic estimates. (a) Profile crossing Johns River, southern Washington. (b) Profile crossing Siletz, northern Oregon.

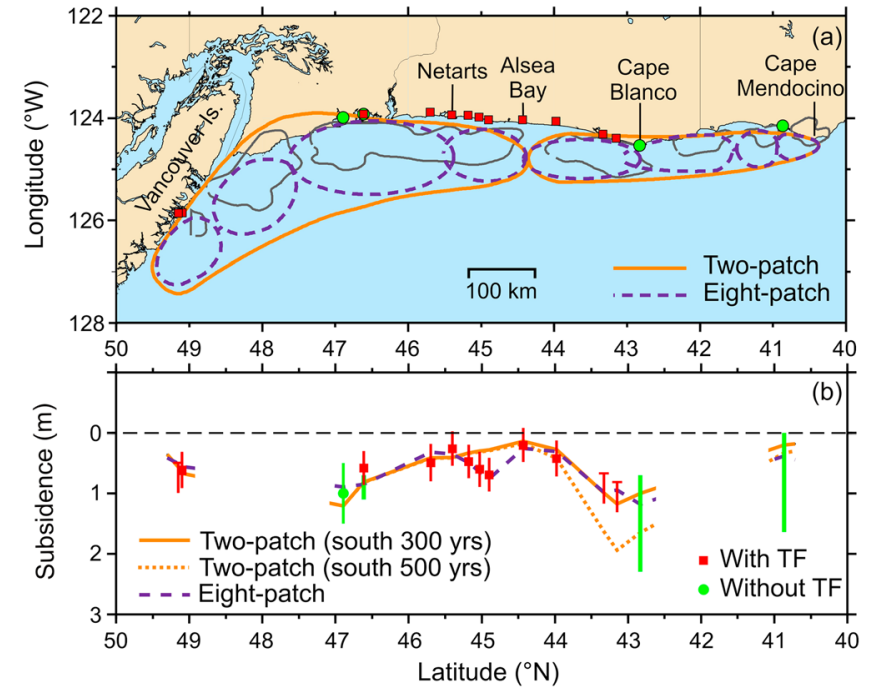

Figure 10. Test models with different numbers of high-slip patches. (a) Outlines of high-slip patches. Gray lines delineate offshore basins inferred from gravity anomalies by Wells et al. [2003]. (b) Model subsidence. For the two-patch model (orange), slip of the north patch is 450 years, and slip of the south patch is 300 or 500 years.

[48] The first test is a two-patch model (Table 2 and Figure 10a). The segment boundary off Alsea Bay is the same as in the preferred model and hence can explain the low subsidence in this area. However, with only one segment boundary, this model cannot explain the shortwavelength variations of coastal subsidence near $45^{\circ} \mathrm{N}$ (Figure 10b). If the peak slip of the southern patch is 300 years, the model-predicted subsidence at Cape Blanco may be too small (Figure 10b). If the slip is increased to 500 years, the model better fits the paleoseismic estimate at Cape Blanco but overpredicts subsidence at Coquille $\left(43.15^{\circ} \mathrm{N}\right)$ (Figure 10b). This example further explains why three segment boundaries are needed by the preferred model (see section 4.2).

[49] A second test with an eight-patch model is motivated by the observation that some of the segment boundaries in our preferred model are in agreement with boundaries of offshore basins inferred from gravity lows by Wells et al. [2003]. The eight-patch model is constructed by dividing the northernmost and southernmost high-slip patches of the preferred model each into three smaller patches roughly according to the distribution of fore-arc basins (Figure 10a). As shown in Figure 10b, where subsidence estimates are available, this model predicts a subsidence pattern similar to that of the preferred model (Figure 6c). Although we do not introduce boundaries in data gaps for the preferred model, there are arguments for some boundaries in northern Cascadia as portrayed by the eight-patch model. For example, BlaisStevens et al. [2011] proposed that records of earthquakeinduced debris flow off Vancouver Island indicate an average earthquake recurrence interval much shorter than that off southern Washington, although it is uncertain whether all debris flows were triggered by megathrust earthquakes. Based on the offshore turbidite records, Atwater and Griggs [2012] also suggest a shorter recurrence interval off Vancouver Island. 


\section{Conclusions}

[50] Like all instrumentally recorded large subduction earthquakes worldwide, great Cascadia earthquakes must have exhibited heterogeneous coseismic slip. Past Cascadia earthquake models assumed uniform along-strike rupture because the large scatter and errors of paleoseismic subsidence estimates did not allow resolution for higher-order variations. In this work, we use recent, more precise estimates of coseismic subsidence, in most cases based on transfer function analyses of intertidal foraminifera.

[51] We propose a rupture scenario for the $M \sim 9$ earthquake of A.D. 1700 consisting of high-slip patches separated by lowslip areas. The surface deformation is modeled using a 3-D elastic half-space dislocation model. The locations of the high- and low-slip areas are constrained by estimates of coseismic subsidence based on microfossil analyses. Our preferred model (Figure 6a) consists of four high-slip patches. There are two large areas in northern and southern Cascadia where transfer-function-based microfossil paleoseismic data are either very inadequate or nonexistent. Therefore, the slip values of these parts of our model are not or very poorly constrained in these areas. For lack of constraints and for simplicity, we have assigned large patches to these areas in the preferred model, but we by no means exclude the possibility of more heterogeneous rupture in these areas. The model serves as a working hypothesis for the A.D. 1700 rupture testable by future paleoseismic observations.

[52] Locations of some of our low-slip areas correlate to some degree with previously proposed segmentation boundaries or, at two locations, subducting seamounts. Locations of high-slip patches tend to correspond with basincentered coseismic slip proposed by Wells et al. [2003]. If our model can be validated by more paleoseismic subsidence estimates, it raises an important question whether the low-slip areas are controlled by geological processes. Geologically controlled, persistent slip behavior of different segments of the megathrust fault has implications for seismic hazard mapping.

[53] Although the coastal subsidence data used here help define along-strike variations of coseismic slip, they cannot constrain rupture width in the dip direction. Because of the lack of data coverage in the dip direction, there is a tradeoff between slip magnitude and the position of the downdip rupture limit. A wider rupture with smaller slip and a narrower rupture with greater slip can both fit the paleoseismic data (Figure 8). Ignoring physical reasoning, one can even explain the paleoseismic coastal subsidence variations by varying the rupture width alone while assuming a uniform slip (Figure 5). Also, the coastal data contain no information on the rupture behavior of the updip half of the rupture zone. Although, in our preferred model, the slip decreases to zero at the deformation front, it does not exclude the possibility of large slip of the shallow part of the fault (Figure 6b).

[54] Acknowledgments. We thank J. P. Guilbault for providing original data from Guilbault et al. [1995, 1996] and J. A. R. Sabean for providing data from Sabean [2004]. This research was supported by an NSF grant (EAR-0842728) to BPH and by the Earthquake Hazards Program of the U.S. Geological Survey. PLW was partially supported by a University of Victoria graduate scholarship. This paper is a contribution to IGCP Project 588 and also Geological Survey of Canada contribution 20120185 .

\section{References}

Atwater, B. F. (1992), Geologic evidence for earthquakes during the past 2000 years along the Copalis River, southern coastal Washington, J. Geophys. Res., 97, 1901-1919, doi:10.1029/91JB02346.

Atwater, B. F., and G. B. Griggs (2012), Deep-sea turbidites as guides to Holocene earthquake history at the Cascadia subduction zone-Alternative views for a seismic-hazard workshop, U.S. Geological Survey Open-File Report, 2012-1043, 58 p., available at http://pubs.usgs.gov/ of $/ 2012 / 1043 /$

Atwater, B. F., and E. Hemphill-Haley (1997), Recurrence intervals for great earthquakes of the past 3500 years at northeastern Willapa Bay, Washington, U.S. Geol. Surv. Prof. Pap., 1576, 108.

Atwater, B. F., and D. Yamaguchi (1991), Sudden, probably coseismic submergence of Holocene trees and grass in coastal Washington state, Geology, 19(7), 706-709.

Atwater, B. F., M. P. Tuttle, E. S. Schweig, C. M. Rubin, D. K. Yamaguchi, and E. Hemphill-Haley (2004), Earthquake recurrence inferred from paleoseismology, in The Quaternary Period in the United States, edited by A. R. Gillespie et al., pp. 331-350, Elsevier Science, New York.

Atwater, B. F., S. Musumi-Rokkaku, K. Satake, Y. Tsuji, K. Ueda, and D. K. Yamaguchi (2005), The orphan tsunami of 1700-Japanese clues to a parent earthquake in North America, U.S. Geol. Surv. Prof. Paper, 1707.

Blais-Stevens, A., G. C. Rogers, and J. J. Clague (2011), A revised earthquake chronology for the last 4,000 years inferred from varve-bounded debris-flow deposits beneath an inlet near Victoria, British Columbia, Bull. Seismol. Soc. Am., 101, 1-12, doi:10.1785/0120090360.

Birks, H. J. B. (1995), Quantitative palaeoenvironmental reconstructions, in Statistical Modeling of Quaternary Science Data, edited by D. Maddy and J. Brew., pp. 161-236, Technical Guide No. 5, Quaternary Research Association, Cambridge, UK.

Chlieh, M., J.-P. Avouac, V. Hjorleifsdottir, T.-R. A. Song, C. Ji, K. Sieh, A. Sladen, H. Hebert, D. H. Natawidjaja, and J. Galetzka (2007), Coseismic slip and afterslip of the great $\left(\mathrm{M}_{\mathrm{W}}\right.$ 9.15) Sumatra-Andaman earthquake of 2004, Bull. Seismol. Soc. Am., 97, S152-S173, doi:10.1785/0120050631.

Clague, J. J., P. T. Bobrowsky, and I. Hutchinson (2000), A review of geological records of large tsunamis at Vancouver Island, British Columbia, and implications for hazard, Quat. Sci. Rev., 19, 849-863.

Cohen, S. C., and J. T. Freymueller (2001), Crustal uplift in the south central Alaska subduction zone: New analysis and interpretation of tide gauge observations, J. Geophys. Res., 106, 653-668.

Darienzo, M. E., C. D. Peterson, and C. Clough (1994), Stratigraphic evidence for great subduction-zone earthquakes at four estuaries in northern Oregon, U.S.A, J. Coast. Res., 10(4), 850-876.

DeMets, C., R. G. Gordon, and D. F. Argus (2010), Geologically current plate motions, Geophys. J. Int., 181, 1-80.

Engelhart, S. E., B. P. Horton, C. H. Vane, A. R. Nelson, R. C. Witter, S. R. Brody, and A. D. Hawkes (2013), Modern foraminifera and stable carbon isotopes of central Oregon tidal marshes and their application in paleoseismology, Palaeogeography, Palaeoclimatology, Palaeoecology, in press.

Flück, P., R. D. Hyndman, and K. Wang (1997), Three-dimensional dislocation model for great earthquakes of the Cascadia subduction zone, J. Geophys. Res., 102(20), 539-550.

Fujiwara, T., S. Kodaira, T. No, Y. Kaiho, N. Takahashi, and Y. Kaneda (2011), Tohoku-Oki earthquake: Displacement reaching the trench axis, Science, 334:1240, doi:10.1126/science.1211554.

Gehrels, W. R., B. W. Hayward, R. M. Newnham, K. E. Southall (2008), A $20^{\text {th }}$ century acceleration of sea-level rise in New Zealand. Geophys. Res. Lett., 35(L02717), doi:10.1029/2007GL032632.

Goldfinger, C., et al. (2012), Turbidite event history: Methods and implications for Holocene paleoseismicity of the Cascadia subduction zone, U.S. Geol. Surv. Prof. Pap., 1661-F.

Guilbault, J. P., J. J. Clague, and M. Lapointe (1995), Amount of subsidence during a late Holocene earthquake-Evidence from fossil tidal marsh foraminifera at Vancouver Island, west coast of Canada, Palaeogeography, Palaeoclimatology, Palaeoecology, 118, 49-71, doi:10.1016/0031-0182 (94)00135-U.

Guilbault, J. P., J. J. Clague, and M. Lapointe (1996), Foraminifera evidence for the amount of coseismic subsidence during a late Holocene earthquake on Vancouver Island, west coast of Canada, Quat. Sci. Rev., 15, 913-937, doi:10.1016/S0277-3791(96)00058-3.

Hamilton, S.L., and I. Shennan (2005), Late Holocene land and sea-level changes and the earthquake deformation cycle around the upper Cook Inlet, Alaska, Quat. Sci. Rev., 24, 1479-1498, doi:10.1016/j.quascirev.2004.11.003.

Han, S., S. M. Carbotte, J. P. Canales, H. D. Carton, and M. R. Nedimovic (2012), Along-trench structural variations of downgoing Juan de Fuca Plate in relation to regional scale segmentation of the Cascadia subduction 
zone: Insights from multichannel seismic imaging, AGU Fall Meeting, Abstract T11A-2523.

Hawkes, A. D., D. B. Scott, J. H. Lipps, and R. Combellick (2005), Evidence for possible precursor events of megathrust earthquakes on the west coast of North America. Geol. Soc. Am. Bull., 117, 996-1008, doi:10.1130/ B25455.1.

Hawkes, A. D., B. P. Horton, A. R. Nelson, and D. F. Hill (2010), The application of intertidal foraminifera to reconstruct coastal subsidence during the giant Cascadia earthquake of AD 1700 in Oregon, Quat. Int., 221, 116-140, doi:10.1016/j.quaint.2009.09.019.

Hawkes, A. D., B. P. Horton, A. R. Nelson, C. H. Vane, and Y. Sawai (2011), Coastal subsidence in Oregon, USA, during the giant Cascadia earthquake of AD 1700, Quat. Sci. Rev., 30, 364-376, doi:10.1016/j. quascirev.2010.11.017.

Hemphill-Haley, E. (1995), Diatom evidence for earthquake induced subsidence and tsunami $300 \mathrm{yr}$ ago in southern coastal Washington, Geological Society of America Bulletin, 107, 367-378.

Horton, B. P., and R. J. Edwards (2006), Quantifying Holocene sea-level change using intertidal foraminifera: Lessons from the British Isles, Cushman Found. Foram. Res., Special Publication, 40, 97 pp.

Horton, B. P., R. J. Edwards, and J. M. Lloyd (1999), UK intertidal foraminiferal distributions: Implications for sea-level studies, Marine Micropaleontology, 36, 205-223.

$\mathrm{Hu}$, Y., and K. Wang (2008), Coseismic strengthening of the shallow portion of the subduction fault and its effects on wedge taper, J. Geophys. Res., 113, B12411, doi:10.1029/2008JB005724.

Hughes, J. F., R. W. Mathewes, and J. J. Clague (2002), Use of pollen and vascular plants to estimate coseismic subsidence at a tidal marsh near Tofino, British Columbia, Palaeogeography, Palaeoclimatology, Palaeoecology, 185, 145-161, doi:10.1016/S0031-0182(02)00283-3.

Hyndman, R. D., and K. Wang (1993), Thermal constraints on the zone of major thrust earthquake failure: The Cascadia subduction zone, J. Geophys. Res., 98, 2039-2060, doi:10.1029/92JB02279.

Hyndman, R. D., and K. Wang (1995), The rupture zone of Cascadia great earthquakes from current deformation and thermal constraints on the zone of potential great earthquakes on the Cascadia subduction thrust, $J$. Geophys. Res., 100(22), 133-154.

Imbrie, J., and N. G. Kipp (1971), A new micropalaeontological method for quantitative paleoclimatology: Application to a late Pleistocene Caribbean core, in The Late Cenozoic Glacial Ages, edited by K. K Turekian, pp. 71-181, Yale University Press, New Haven and London.

Juggins, S. (2011), C2 Release 1.7.2. http://www.staff.ncl.ac.uk/staff/stephen. juggins/software/C2Home.htm. University of Newcastle, United Kingdom.

Kelsey, H. M., R. C. Witter, and E. Hemphill-Haley (1998), Response of a small Oregon estuary to coseismic subsidence and postseismic uplift in the past 300 years, Geology, 26(3), 231-234.

Kelsey, H. M., R. C. Witter, and E. Hemphill-Haley (2002), Plate-boundary earthquakes and tsunamis of the past 5500 years, Sixes River estuary, southern Oregon, Geol. Soc. Am. Bull., 114, 298-314.

Kelsey, H. M., A. R. Nelson, E. Hemphill-Haley, R. Witter (2005), Tsunami history of an Oregon coastal lake reveals a $4600 \mathrm{yr}$ record of great earthquakes on the Cascadia subduction zone, Geol. Soc. Am. Bull., 117, 1009-1032, doi:10.1130/B25452.1.

Kemp, A. C., B. P. Horton, J. P. Donnelly, M. E. Mann, M. Vermeer, and S. Rahmstorf (2011), Climate related sea-level variations over the past two millennia, Proc. Natl. Acad. Sci. USA, 108, 11017-11022, doi:10.1073/ pnas.1015619108.

Kodaira, S., T. No, Y. Nakamura, T. Fujiwara, Y. Kaiho, S. Miura, N. Takahashi, Y. Kaneda, and A. Taira (2011), Coseismic fault rupture at the trench axis during the 2011 Tohoku-oki earthquake, Nat. Geosci., 5, 646-650, doi:10.1038/ngeo1547.

Lee, S.-J., B.-S. Huang, M. Ando, H.-C. Chiu, and J.-H. Wang (2011), Evidence of large scale repeating slip during the 2011 Tohoku-Oki earthquake, Geophys. Res. Lett., 38, L19306, doi:10.1029/2011GL049580.

Leonard, L. J., R. D. Hyndman, and S. Mazzotti (2004), Coseismic subsidence in the 1700 great Cascadia earthquake: Coastal estimates versus elastic dislocation models, Geol. Soc. Am. Bull., 116, 655-670, doi:10.1130/ B25369.1.

Leonard, L. J., C. A. Currie, S. Mazzotti, and R. D. Hyndman (2010), Rupture area and displacement of past Cascadia great earthquakes from coastal coseismic subsidence, Geol. Soc. Am. Bull., 122, 2079-2096, doi:10.1130/B30108.1.

Lorito, S., F. Romano, S. Atzori, X. Tong, A. Avallone, J. McCloskey, M. Cocco, E. Boschi, and A. Piatanesi (2011), Limited overlap between the seismic gap and coseismic slip of the great 2010 Chile earthquake, Nat. Geosci., 4(3), 173-177, doi:10.1038/ngeo1073.

McCaffrey, R., A. I. Qamar, R. W. King, R. Wells, G. Khazaradze, C. A. Williams, C. W. Stevens, J. J. Vollick, and P. C. Zwick (2007), Fault locking, block rotation and crustal deformation in the Pacific Northwest, Geophys. J. Int., 169, 1315-1340, doi:10.1111/j.1365246X.2007.03371.
McCrory, P. A. , J. L. Blair, S. H. Oppenheimer, and S. R. Walter (2004), Depth to the Juan de Fuca slab beneath the Cascadia subduction margin-A 3-D model for sorting earthquakes, US Geological Survey Data Series DS-91.

Nelson, A. R., and K. Kashima (1993), Diatom zonation in southern Oregon tidal marshes relative to vascular plants, foraminifera, and sea level, Journal of Coastal Research, 9, 673-697.

Nelson, A. R., et al. (1995), Radiocarbon evidence for extensive plateboundary rupture about 300 years ago at the Cascadia subduction zone, Nature, 378, 371-374.

Nelson, A. R., I. Shennan, and A. J. Long (1996a), Identifying coseismic subsidence in tidal-wetland stratigraphic sequences at the Cascadia subduction zone of western North America, J. Geophys. Res., 101(B3), 6115-6135, doi:10.1029/95JB01051.

Nelson, A. R., A. E. Jennings, and K. Kashima (1996b), An earthquake history derived from stratigraphic and microfossil evidence of relative sea-level change at Coos Bay, southern coastal Oregon, Geol. Soc. Am. Bull., 108, 141-154.

Nelson, A.R., Kelsey, H.M., and Witter, R.C. (2006), Great earthquakes of variable magnitude at the Cascadia subduction zone, Quat. Res., 65, 354-365, doi:10.1016/j.yqres.2006.02.009.

Nelson, A. R., Y. Sawai, A. E. Jennings, L.-A. Bradley, L. Gerson, B. L. Sherrod, J. Sabean, and B. P. Horton (2008), Great-earthquake paleogeodesy and tsunamis of the past 2000 years at Alsea Bay, central Oregon coast, Quat. Sci. Rev., 27, 747-768, doi:10.1016/j. quascirev.2008.01.001.

Noda, H., and N. Lapusta (2013), Stable creeping fault segments can become destructive as a result of dynamic weakening, Nature, 493, 521528, doi:10.1038/nature11703.

Okada, Y. (1985), Surface deformation due to shear and tensile faults in a halfspace, Bull. Seism. Soc. Am., 75, 1135-1154.

Peterson, C. D., D. L. Doyle, and E. T. Barnett (2000), Coastal flooding and beach retreat from coseismic subsidence in the central Cascadia margin, USA, Env. Eng. Geosci., 6, 255-269.

Porritt, R. W., R. M. Allen, D. C. Boyarko, and M. R. Brudzinski (2011), Investigation of Cascadia segmentation with ambient noise tomography, Earth Planet. Sci. Lett., 309, 67-76, doi:10.1016/j.eps1.2011.06.026.

Priest, G. R., K. Wang, Y. Zhang, C. Goldfinger, R. Witter, C. D. Peterson, K. Cruikshank, A. M. Baptista, C. Seaton, and P. Turner (2010), Confidence levels for tsunami-inundation limits in northern Oregon inferred from a 10,000-year history of great earthquakes at the Cascadia subduction zone, Nat. Hazards., 54, 27-73, doi: 10.1007/s11069-009-9453-5

Pritchard, C. J. (2004), Late Holocene relative sea-level changes, Arcata Bay, California: Evaluation of freshwater syncline movement using coseismically buried soil horizons, M.S. thesis, Arcata, California, Humboldt State University, Department of Geology, $56 \mathrm{p}$.

Sabean, J.A.R. (2004), Applications of foraminifera to detecting land level change associated with great earthquakes along the west coast of North America, M.Sc. thesis, Burnaby, British Columbia, Simon Fraser University, $90 \mathrm{p}$.

Satake, K., K. Wang, and B. F. Atwater (2003), Fault slip and seismic moment of the 1700 Cascadia earthquake inferred from Japanese tsunami descriptions, J. Geophys. Res., 108, 2325, doi:10.1019/ 2003JB002521.

Shennan, I., and S. Hamilton (2006), Coseismic and pre-seismic subsidence associated with great earthquakes in Alaska, Quat. Sci. Rev., 25, 1-8.

Shennan, I., A. J. Long, M. M. Rutherford, F. M. Green, J. B. Innes, J. M. Lloyd, Y. Zong, and K. J. Walker (1996), Tidal marsh stratigraphy, sealevel change and large earthquakes: I. A 5000 year record in Washington, Quat. Sci. Rev., 15, 1023-1059, doi: 10.1016/S0277-3791(96)00007-8

Shennan, I., A. J. Long, M. M. Rutherford, J. B. Innes, F. M. Green, and K. J. Walker (1998), Tidal marsh stratigraphy, sea-level change and large earthquakes: II. Submergence events during the last 3500 years at Netarts Bay, Oregon, Quaternary Science Reviews, 17, 365-393, doi:10.1016/S02773791(97)00055-3.

Takada, K., and B. F. Atwater (2004), Evidence for liquefaction identified in peeled slices of Holocene deposits along the lower Columbia River, Washington, Bull. Seismol. Soc. Am., 94, 550-575, doi:10.1785/0120020152.

Tréhu, A. M., R. J. Blakely, and M. C. Williams (2012), Subducted seamounts and recent earthquakes beneath the central Cascadia forearc, Geology, 40(2), 103-106, doi:10.1130/G32460.1.

Wang, K., and S. L. Bilek (2011), Do subducting seamounts generate or stop large earthquakes?, Geology, 39(9), 819-822. doi:10.1130/G31856.1.

Wang, K., and J. He (2008), Effects of frictional behaviour and geometry of subduction fault on coseismic seafloor deformation, Bull. Seismol. Soc. Am., 98(2), 571-579, doi:10.1785/0120070097.

Wang, K., R. Wells, S. Mazzotti, R. D. Hyndman, and T. Sagiya (2003), A revised dislocation model of interseismic deformation of the Cascadia subduction zone, J. Geophys. Res., 108(B1), 2026, doi:10.1029/ 2001JB001227. 
WANG ET AL.: GREAT CASCADIA EARTHQUAKE OF 1700

Wang, K., Y. Hu, and J. He (2012), Deformation cycles of subduction earthquakes in a viscoelastic Earth, Nature, 484, 327-332, doi:10.1038/ nature 11032.

Wei, S., R. Graves, D. Helmberger, J.-P. Avouac, and J. Jiang (2012), Sources of shaking and flooding during the Tohoku-Oki earthquake: A mixture of rupture styles. Earth Planet Sci. Lett., 333-334, 91-100, doi:10.1016/j.epsl.2012.04.006.

Wells, R. E., and R. W. Simpson (2001), Northward migration of the Cascadia forearc in the northwestern U. S. and implications for subduction deformation, Earth Planets Space, 53, 275-283.

Wells, R. E., R. J. Blakely, Y. Sugiyama, D. W. Scholl, and P. A. Dinterman (2003), Basin-centered asperities in great subduction zone earthquakes: A link between slip, subsidence, and subduction erosion?, J. Geophys. Res., 108(B10), 2507, doi:10.1029/2002JB002072.

Wilson, D. S. (1993), Confidence intervals for motion and deformation of the Juan de Fuca plate, J. Geophys. Res., 98, 16,053-16,071.

Witter, R. C., H. M. Kelsey, and E. Hemphill-Haley (2003), Great Cascadia earthquakes and tsunamis of the past 6700 years, Coquille River estuary, southern coastal Oregon, Geol. Soc. Am. Bull., 115, 1289-1306, doi:10.1130/B25189.1.

Yokota, Y., K. Koketsu, Y. Fujii, K. Satake, S. Sakai, M. Shinohara, and T. Kanazawa (2011), Joint inversion of strong motion, teleseismic, geodetic, and tsunami datasets for the rupture process of the 2011 Tohoku earthquake, Geophys. Res. Lett., 38, L00G21, doi:10.1029/2011GL050098. 